\title{
TEKNIK PEMBIBITAN, PEMUPUKAN, DAN PENGENDALIAN HAMA PENYAKIT TANAMAN KOMODITI JERUK SIAM (Citrus nobilis var. microcarpa) DI KECAMATAN SIMPANG EMPAT DAN KECAMATAN PAYUNG, KABUPATEN KARO, SUMATRA UTARA, INDONESIA
}

\author{
Endang Christine Purba ${ }^{1}$ dan Bambang S. Purwoko ${ }^{2}$ \\ ${ }^{1}$ Puri Kintamani Blok C6/8, Cilebut-Bogor, Indonesia \\ ${ }^{2}$ Fakultas Pertanian, Institut Pertanian Bogor, Indonesia \\ * Corresponding author : endang.christine@yahoo.com
}

\begin{abstract}
Citrus is one of the horticultural commodities that has been a focus of development in 2018. Citrus is the fourth largest commodity in the percentage of Indonesia fruit production in 2014. In 2014, citrus fruit production in Indonesia was 1,785,256 tons or around $9.01 \%$ of national fruit production. Karo Regency is a citrus production center in North Sumatra, Indonesia. According to the Direktorat Jendral Hortikultura (2015) the production of citrus commodities was 173.921 tons $(53,30 \%)$. In 2014, there were 3,150,060 productive citrus trees with a harvested area of 7,875 ha and a production of 500,243 tons in North Sumatra. One of the varieties grown by farmers in Karo Regency is Siam. High productivity of siam is certainly also influenced by seedlings, fertilization and controlling the pests. To determine this, research has been conducted on farmers in Simpang Empat and Payung Districts, Karo Regency, North Sumatra, Indonesia. To get quality Siam seeds, farmers in two research locations used Japansche citroen plants as rootstock because they were resistant to disease and drought. Fertilization of siam uses inorganic fertilizer as much as 3-4 months, while organic fertilizer as much as 10 months. The control of pests of siam citrus is done mechanically and chemically. Pests and diseases that usually attack siam are Bractocera spp, black lice, fruit borers, fungus and powdery mildew.
\end{abstract}

Keywords: cultivation, seedling, fertilizer, pest, productivity, orange, Citrus nobilis

\section{PENDAHULUAN}

Jeruk merupakan salah satu komoditas hortikultura yang menjadi fokus pengembangan di 57 kabupaten/kota kawasan pengembangan untuk peningkatan diversifikasi pangan pada tahun 2018 (Balai Penelitian Tanaman Jeruk dan Buah Subtropika, 2017). Jeruk merupakan komoditi keempat terbesar dalam persentase produksi buah di Indonesia pada tahun 2014. Hal ini menyebabkan tanaman jeruk banyak diusahakan di Indonesia. Pada tahun 2014, produksi buah jeruk di Indonesia adalah 1.785.256 ton atau sekitar 9,01\% terhadap produksi buah nasional (Direktorat Jendral Hortikultura, 2015). Perbandingan luas panen jeruk meningkat dari tahun 2013 sampai 2014 yaitu sebesar 48,154 Ha menjadi 51,098 Ha. Pada perbandingan tahun yang sama, jumlah produksi jeruk meningkat dari 1.548.394 ton menjadi 1.785.256 ton.

Jeruk termasuk salah satu komoditas unggul buah-buahan di Indonesia. Terdapat beberapa varietas jeruk komersial yang sudah dikembangkan dan dikenal baik masyarakat Indonesia antara lain Siam Pontianak, Siam Medan, Siam Sambas dan Keprok SoE (Ashari, 2014). Lebih lanjut lagi, sektor usaha tani untuk buah jeruk di Indonesia masih didominasi $80 \%$ oleh jeruk Siam karena produktivitasnya yang tinggi (Ashari, 2014). 
Penyebaran jeruk siam tersebar dari dataran rendah sampai dataran tinggi.

Salah satu sentra produksi jeruk Indonesia adalah Provinsi Sumatra Utara. Pada tahun 2014, Sumatra Utara merupakan produsen jeruk terbesar di Indonesia setelah Jawa Timur, yaitu sebesar $28,02 \%$ dari total produksi buah jeruk nasional Indonesia (Direktorat Jendral Hortikultura, 2015). Pada tahun 2014 terjadi peningkatan produksi sebesar 173.921 ton atau 53,30\%. Peningkatan disebabkan oleh adanya pengendalian lalat buah (Direktorat Jendral Hortikultura, 2015). Pada tahun 2014, tercatat sebanyak 3.150.060 pohon jeruk yang produktif dengan luas panen sebesar $7.875 \mathrm{Ha}$ dan produksi sebanyak 500.243 ton di Sumatra Utara. Sentra produksi jeruk di Sumatra Utara adalah Kabupaten Karo. Salah satu varietas jeruk yang ditanam di Kabupaten Karo adalah siam. Jeruk siam merupakan salah satu komoditas unggulan yang dapat dikembangkan karena kondisi tanah yang cocok. Jeruk siam berasal adri Siam dan memiliki kulit buah yang lebih tipis dari jeruk lainnya, kulit buah berwarna hijau kekuningan, daging buah yang tidak berongga dan memiliki kandungan air yang tinggi (Endarto dan Martini, 2016).

Menurut Sutopo (2014), selain pemilihan bibit jeruk unggul keberhasilan budidaya jeruk juga dipengaruhi oleh pemilihan lokasi, penyiapan lahan dan pemeliharaan tanaman. Penyebab utama hasil panen jeruk yang rendah disebabkan oleh penggunaan bibit yang kurang baik dan gangguan hama penyakit tanaman. Bibit yang baik harus bebas dari penyakit, tinggi tanaman $\pm 75 \mathrm{~cm}$ dan perakaran yang tidak bengkok. Hama dan penyakit yang menjadi penyebab terbesar penurunan produksi jeruk secara signifikan adalah lalat buah dan penyakit CVPD (Citrus Vein Phloem Degeneration). Menurut Wijaya et al. (2017), lalat buah dapat menyebabkan pengurangan produksi buah, bercak pada buah, busuk dan berlubang. Untuk menunjang kebutuhan nutrisi tanaman maka ketersediaan hara dalam tanah haruslah memadai. Untuk itu diperlukan pemupukan di kebun jeruk siam yang seimbang karena pemupukan salah satu unsur hara yang berlebihan maka akan menyebabkan gangguan pada penyerapan unsur hara lainnya. Pemupukan yang tidak benar dapat menyebabkan kemunduran lahan yaitu menurunnya kesuburan tanah, kerusakan sifat fisik dan biologis dan menipisnya ketebalan tanah (Rambe dan Ivanti, 2013). Lebih lanjut, akan terjadi peningkatan dosis dan jenis unsur hara pupuk yang diberikan di saat semakin lamanya budidaya jeruk siam di lahan. Untuk mengetahui teknik budidaya jeruk siam di Kabupaten Karo, maka dilakukan penelitian ini untuk mengungkap cara pembibitan, pemupukan dan pengendalian hama penyakit di salah satu sentra produksi jeruk terbesar di Indonesia. 
Endang Christine Purba \& Bambang S. Purwoko: Teknik Pembibitan, Pemupukan, dan Pengendalian Hama Penyakit Tanaman Komoditi Jeruk Siam (Citrus Nobilis Var. Microcarpa) di Kecamatan Simpang Empat dan Kecamatan Payung, Kabupaten Karo, Sumatra Utara, Indonesia

\section{METODE PENELITIAN}

\section{Lokasi Penelitian}

Penelitian dilakukan di bulan FebruariMaret di Kecamatan Simpang Empat dan Kecamatan Payung, Kabupaten Karo, Sumatra Utara, Indonesia. Secara geografis Kabupaten Karo terletak diantara $2^{0} 50^{\prime}-3^{0} 19^{\prime}$ ' Lintang Utara dan $97^{0} 55^{\prime}-98^{0} 38^{\prime}$ Bujur Timur dengan luas 2.127,25 $\mathrm{km}^{2}$ (Pemerintah Daerah Kabupaten Karo, 2017). Wilayah Kabupaten Karo merupakan dataran tinggi yang berada pada ketinggian 200-1.500 m dpl. Kabupaten Karo berbatasan dengan Kabupaten Langkat dan Kabupaten Deli Serdang di sebelah utara, sebelah selatan dengan Kabupaten Dairi dan Toba Samosir, sebelah timur dengan Kabupaten Deli Serdang dan Kabupaten Simalungun dan sebelah barat dengan Propinsi Daerah Istimewa Aceh.

Kecamatan Simpang Empat berjarak 7 km dari ibu kota Kabupaten Karo, Kabanjahe, Sumatara Utara. Kecamatan Simpang Empat berbatas dengan Kecamatan Kabanjahe sebelah timur, Kecamatan Namanteran sebelah barat, Kecamatan Brastagi sebelah utara, dan Kecamatan Payung sebelah selatan. Kecamatan ini memiliki 17 desa yaitu Desa Tiga Pancur, Desa Surbakti, Desa Ndikum Siroga, Desa Gajah, Desa Nang Belawan, Desa Lingga, Desa Berastepu, Desa Lingga Julu, Desa Bulan Baru, Desa Gamber, Desa Sirumbia dan Desa Kuta Tengah. Berdasarkan data produksi jeruk tahun 2006 produksi jeruk terbesar di Desa Surbakti (6.000 ton), Desa Berastepu (6.000 ton) dan Desa Lingga Julu (7.000 ton).

Kecamatan Simpang Empat memiliki luas 95,48 $\mathrm{km}^{2}$. Berdasarkan data dari Dinas Pertanian Tingkat II Kabupaten Karo (2013), Kecamatan Simpang Empat merupakan sentra produksi buah jeruk di Kabupaten Karo, Sumatra Utara. Luas lahan jeruk sebesar 2.062 ha. Jumlah pohon jeruk yang menghasilkan di Kecamatan Simpang Empat mencapai 969.000 pohon dengan jumlah produksi mencapai 2.348.977 kwintal dan produktivitas sebesar 2,42 kwintal per pohon.

Kecamatan Payung memiliki luas 47,24 $\mathrm{km}^{2}$. Luas lahan jeruk sebesar 175 ha. Kecamatan Simpang Empat berjarak $20 \mathrm{~km}$ dari ibu kota Kabupaten Karo, Kabanjahe, Sumtara Utara. Kecamatan Payung berbatas dengan Kecamatan Kabanjahe dan Kecamatan Simpang Empat sebelah timur, Kecamatan Tiganderket dan Kecamatan Tiga Binanga Brastagi sebelah barat, Kecamatan Tiganderket dan Kecamatan Namanterann sebelah utara dan Kecamatan Munthe sebelah selatan. Kecamatan Payung memiliki 8 desa yaitu Desa Batukarang, Desa Selandi, Desa Rimokayu, Desa Payung, Desa Gurukinayan, Desa Cimbang, Desa Ujung Payung, dan Desa Sukameriah. 


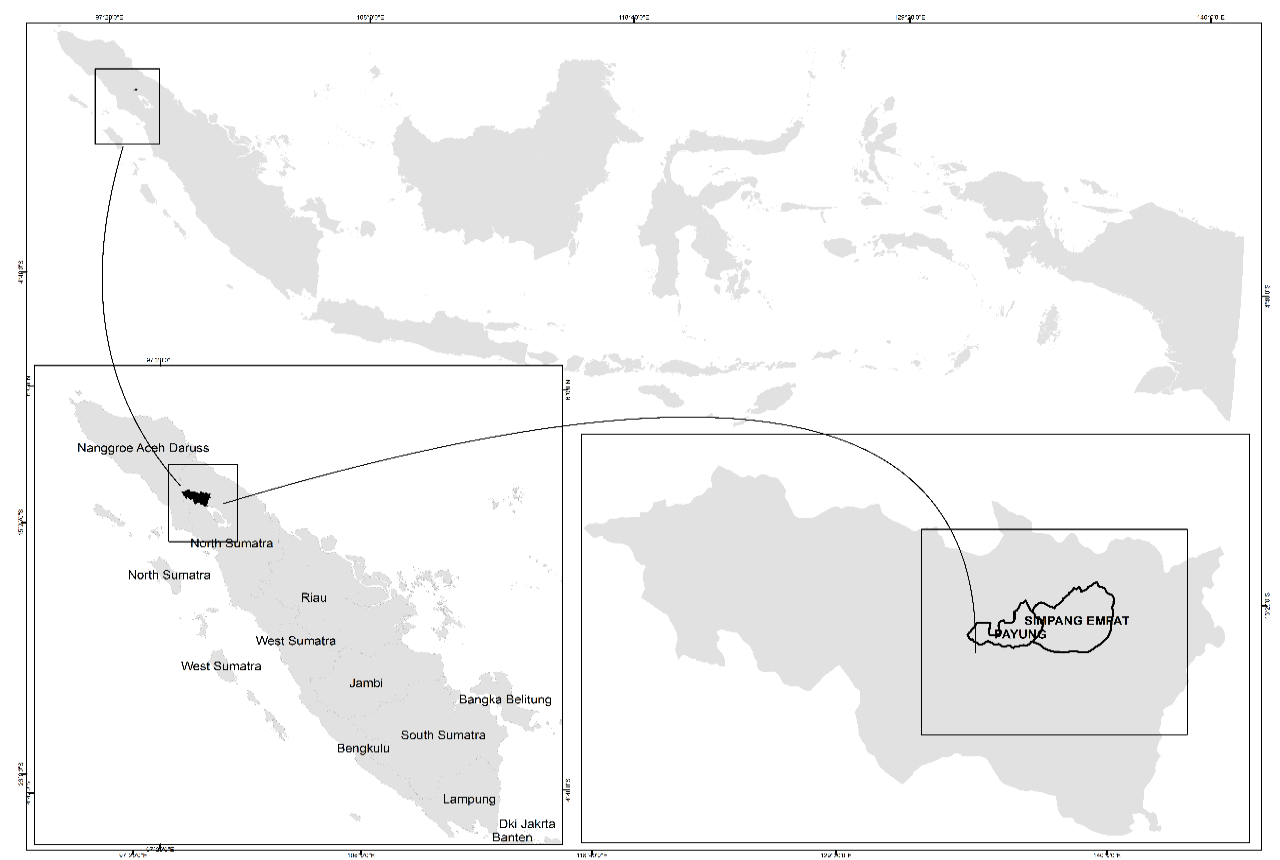

Gambar 1. Lokasi penelitian di Kecamatan Simpang Empat dan Kecamatan Payung, Kabupaten Karo, Sumatra Utara, Indonesia.

\section{Penarikan responden}

Penelitian ini dilakukan di Kecamatan Simpang Empat dan Kecamatan Payung, Kabupaten Karo, Sumatra Utara. Pengambilan data dilakukan di tingkat petani. Petani yang dijadikan responden adalah petani yang menanam buah jeruk siam yaitu 17 petani jeruk siam di Kecamatan Payung dan 20 petani jeruk siam di Kecamatan Simpang Empat.

\section{Pengumpulan dan analisis data}

Data diperoleh melalui pengamatan langsung di lapangan dan wawancara di masing-masing tingkat responden petani. Penelitian ini juga menggunakan data sekunder. Data primer dan sekunder dianalisis secara deskriptif. Pengamatan dilakukan terhadap beberapa variabel budidaya jeruk siam yang meliputi tentang pembibitan, pemupukan dan pengendalian hama dan penyakit tanaman.

\section{HASIL DAN PEMBAHASAN}

Para petani di Kecamatan Simpang Empat dan Kecamatan Payung menganggap pembibitan, pemeliharaan tanaman dan pemupukan merupakan faktor penting untuk mendapatkan produktivitas jeruk siam yang optimal. Balai Penelitian Tanaman Jeruk dan Buah Subtropika (2015) memberikan rekomendasi untuk pengelolaan terpadu kebun jeruk sehat untuk menghasilkan produktivitas jeruk siam yang tinggi. Hal tersebut mencakup 5 hal penting yaitu penggunaan bibit jeruk yang bebas penyakit, pengendalian hama penular penyakit CVPD, sanitasi kebun, pemeliharaan tanaman dan konsolidasi pengelolaan kebun. 
Endang Christine Purba \& Bambang S. Purwoko: Teknik Pembibitan, Pemupukan, dan Pengendalian Hama Penyakit Tanaman Komoditi Jeruk Siam (Citrus Nobilis Var. Microcarpa) di Kecamatan Simpang Empat dan Kecamatan Payung, Kabupaten Karo, Sumatra Utara, Indonesia

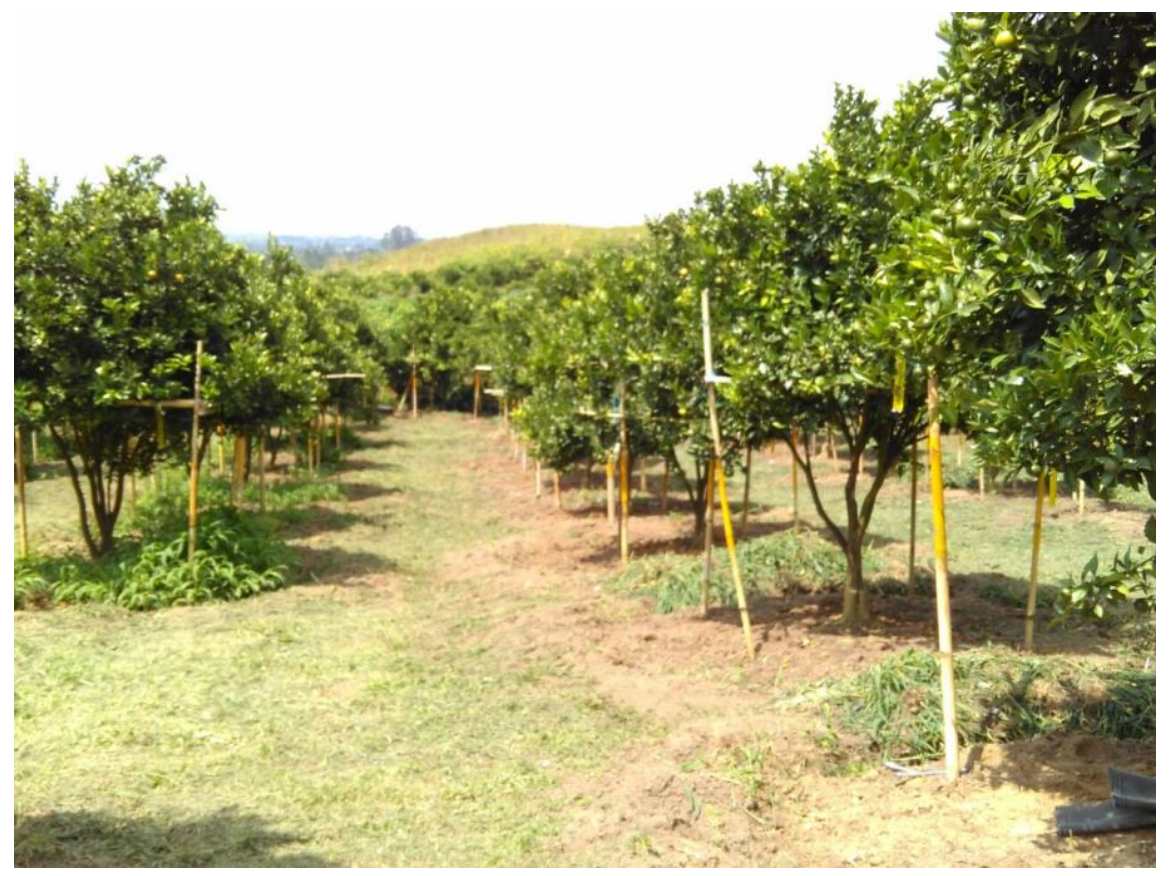

Gambar 2. Kebun jeruk siam di Kabupaten Karo, Sumatra Utara.

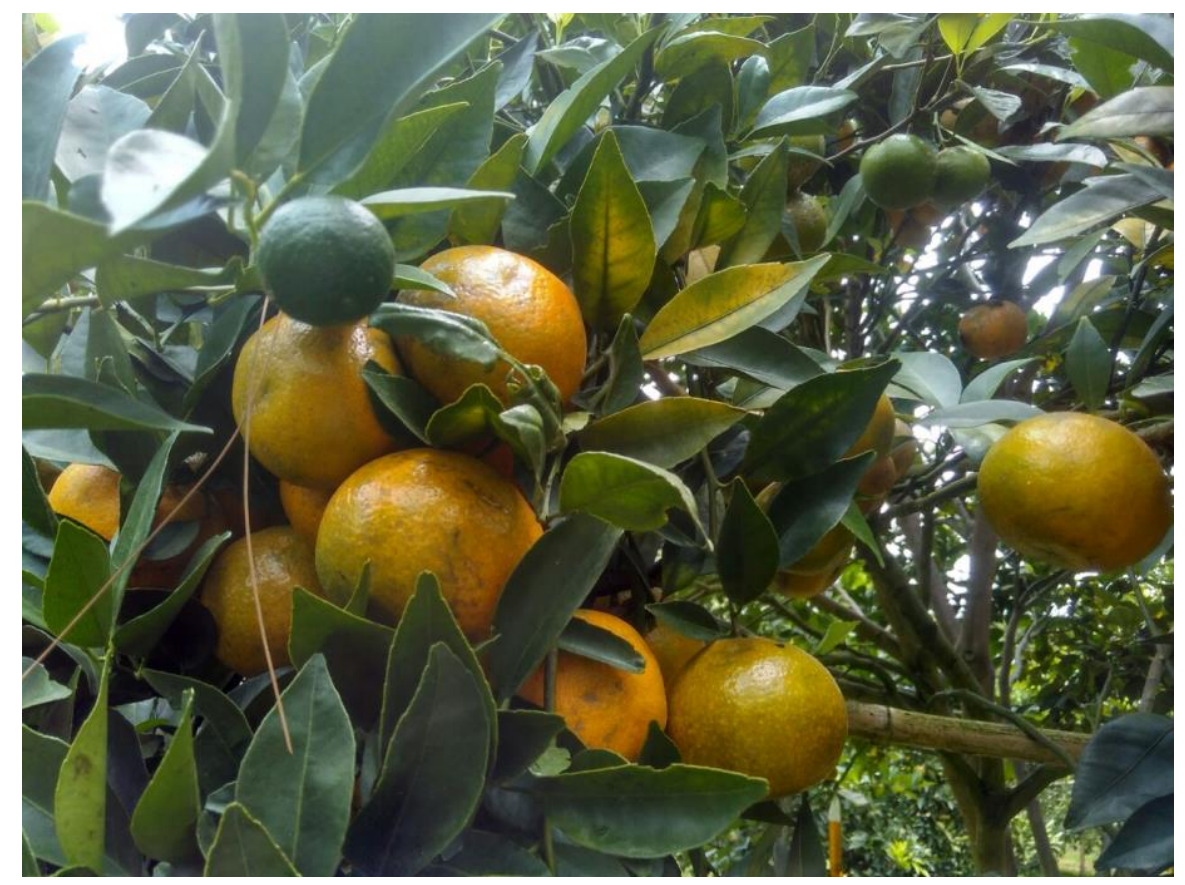

Gambar 3. Buah jeruk siam (Citrus nobilis).

\section{Pembibitan}

Pembibitan sangat mempengaruhi

keberhasilan dalam pelaksanaan budidaya jeruk siam. Bibit jeruk siam dapat diperoleh dengan menggunakan okulasi. Bibit yang dihasilkan memalui okulasi dan ditanam di polibag memiliki akar yang kuat jika dibanding dengan cangkok (Sutopo, 2014). 
Tipe okulasi yang biasanya digunakan adalah okulasi irisan. Menurut Balai Penelitian Tanaman Jeruk dan Buah Subtropika (2007) okulasi irisan adalah cara penempelan dengan mengikutsertakan sebagian kayu pada mata tunas dan sayatan batang bawah. Dengan okulasi irisan, penyatuan dua jaringan hanya mungkin terjadi jika kedua jenis tanaman cocok (kompatibel), irisan luka rata dan pengikatan sambungan tidak terlalu lemah atau tidak terlalu kuat sehingga tidak menyebabkan kerusakan karingan (Sariningtias et al., 2014). Okulasi irisan dapat dilakukan pada batang bawah yang sedang tumbuh tunas baru, batang bawah yang dorman dan mata tunas yang berukuran kecil.

Bibit jeruk yang digunakan untuk usahatani jeruk siam harus bibit yang bebas penyakit dalam kondisi ideal siap tanam. Bibit jeruk harus bebas dari patogen sistemik (CVPD, CTV, Vein enation, Exocortis, Psorosis, Xyloporosis dan Tatter leaf). Untuk mendapatkan bibit yang bermutu, varietas batang bawah dan batang atas harus dijamin kemurniannya serta proses produksinya berdasarkan program sertifikasi jeruk yang berlaku.

Jenis jeruk yang biasanya digunakan oleh petani responden sebagai batang bawah adalah Japansche citroen karena jenis ini lebih tahan terhadap penyakit. Jeruk Japansche citroen memiliki sifat tahan kekeringan, tidak mudah mati saat dicabut untuk dipindahkan pada saat penanaman dan mampu menghasilkan buah yang tinggi (Balai Penelitian Tanaman Jeruk dan Buah Subtropika, 2014) . Benih Japansche citroen disemai dalam polybag yang menggunakan media tanam kompos, tanah dan pasir dengan perbandingan 1:1:1. Bibit Japansche citroen dapat digunakan sebagai batang bawah apabila sudah berumur 6 bulan setelah persemaian. Mata tunas yang digunakan berasal dari jeruk siam yang berumur 4 tahun. Mata tunas diambil dari yang masih berdaun, tidak layu, mata tunas dan tidak pipih.

Perawatan yang biasanya dilakukan selama persemaian Japansche citroen adalah penyiraman 1-2 kali sehari pada pagi dan sore hari. Pemeliharaan yang dilakukan pada bibit okulasi adalah penyiraman 2-3 kali per minggu. Pemupukan bibit okulasi hanya menggunakan pupuk organik.

Rata-rata lahan jeruk siam yang dimiliki oleh petani di Kecamatan Payung adalah 0,44 ha dan di Kecamatan Simpang Empat adalah 0,49 ha (Tabel 1). Petani di Kecamatan Simpang Empat umumnya menanam jeruk siam dengan jarak tanam $4 \mathrm{~m}$ x $5 \mathrm{~m}$, sedangkan petani di Kecamatan Payung adalah 3 m x 4 m. Menurut Joesoef (1993) jarak tanam untuk jeruk siam yang sesuai adalah $5 \mathrm{~m}$ × $5 \mathrm{~m}$ sampai dengan $6 \mathrm{~m} \times 6 \mathrm{~m}$ dengan jumlah populasi 250-400 pohon/ha. 
Endang Christine Purba \& Bambang S. Purwoko: Teknik Pembibitan, Pemupukan, dan Pengendalian Hama Penyakit Tanaman Komoditi Jeruk Siam (Citrus Nobilis Var. Microcarpa) di Kecamatan Simpang Empat dan Kecamatan Payung, Kabupaten Karo, Sumatra Utara, Indonesia

Tabel 1. Karakteristik usahatani jeruk siam di Kecamatan Payung dan Kecamatan Simpang Empat, Kabupaten Karo, Sumatra Utara

\begin{tabular}{lcc}
\hline \multicolumn{1}{c}{ Jenis data } & Kecamatan Simpang Empat & Kecamatan Payung \\
\hline $\begin{array}{l}\text { Kepemilikin lahan rata-rata oleh } \\
\text { petani jeruk (ha) }\end{array}$ & 0,49 & 0,44 \\
Rata-rata populasi/ha & 358 & 345 \\
Rata-rata umur tanaman & 11 & 12 \\
\hline
\end{tabular}

\section{Pemupukan}

Petani di Kecamatan Simpang Empat dan Kecamatan Payung, Kabupaten Karo, Sumatra Utara menggunakan pupuk anorganik dan organik. Pemupukan dilakukan berdasarkan umur tanaman jeruk siam dan kondisi pertumbuhan tanaman. Dosis pupuk akan terus meningkat bersamaan dengan meningkatnya umur tanaman. Petani biasanya melakukan pemupukan 3-4 bulan sekali. Pemupukan akan lebih intensif apabila tanaman jeruk sudah berumur $\geq 4$ tahun. Jumlah masing-masing pupuk yang diperlukan dalam satu tahun di Kecamatan Simpang Empat adalah urea 844 g/pohon, ZA 1.964 g/pohon, SP-36 488 g/pohon, ZK 840 g/pohon dan pupuk organik $1.800 \mathrm{~g} /$ pohon. Sementara itu para petani di Kecamatan Payung menggunakan urea 972 g/pohon, ZA 2.080 g/pohon, SP-36 560 g/pohon, ZK 940 g/pohon dan pupuk organik $1.800 \mathrm{~g} /$ pohon. Petani juga menggunakan pupuk kandang sebagai pupuk organik setiap 10 bulan sekali. Pemupukan organik dapat memenuhi kebutuhan unsur mikro yang dibutuhkan oleh jeruk yaitu besi $9 \mathrm{Fe})$, seng $(\mathrm{Zn})$, mangan $(\mathrm{Mn})$, tembaga $(\mathrm{Cu})$, boron (B) dan molibdenum (Mo) (Sutopo, 2014).

Berdasarkan hasil rekomendasi Endarto dan Martini (2016), pemupukan jeruk dapat dilakukan berdasarkan umur tanaman yaitu 0 5 tahun yaitu menggunakan pupuk kandang dan pupuk Urea, SP36 dan ZK dan berdasarkan jumlah produksi buah pada saat tanaman berumur $>5$ tahun.

Pemberian dosis pupuk ditentukan berdasarkan jenis/varietas, umur, hasil atau biomasa yang dihasilkan tanaman dan faktor lingkungan (Sutopo, 2009). Lebih lanjut lagi pemberian dosis pupuk $\mathrm{N}, \mathrm{P}$, dan $\mathrm{K}$ berdasarkan produksi buah lebih efektif dibandingkan berdasarkan umur tanaman jeruk yaitu pemberian $10 \mathrm{~N}: 1 \mathrm{P}_{2} \mathrm{O}_{5}: 4 \mathrm{~K}_{2} \mathrm{O}$ dengan dosis yang setara dengan $3 \%$ dari produksi buah tanaman jeruk.

\section{Pengendalian hama dan penyakit}

Petani di Kecamatan Simpang Empat dan Kecamatan Payung mengendalikan hama dan penyakit tanaman secara kimiawi dan mekanis. Penyemprotan pestisida disesuaikan dengan hama dan penyakit yang menyerang tanaman jeruk siam. Petani biasanya 
melakukan penyemprotan pestisida sebanyak satu kali dalam 10 hari. Hama dan penyakit yang biasanya menyerang jeruk siam adalah lalat buah Bractocera spp, kutu hitam, penggerek buah, jamur upas dan embun tepung. Petani menggunakan fungisida dengan bahan aktif difenokonazol yang memiliki konsentrasi $200 \mathrm{cc} / 100$ liter air untuk 1.000 $\mathrm{m}^{2}$. Sedangkan insektisida yang digunakan mengandung karbosulfan yang memiliki konsentrasi $200 \mathrm{cc} / 100$ liter air untuk 1.000 $\mathrm{m}^{2}$. Konsentrasi pestisida yang digunakan sesuai dengan tingkat serangan hama dan penyakit di lahan jeruk siam.

Petani juga menggunakan perangkap kuning untuk pengendalian secara mekanis. Perangkap kuning terbuat dari botol plastik bekas yang berwarna kuning dan pada bagian permukaan botol diberi lem perekat. Perangkap kuning digunakan untuk memonitor keberadaan vektor CVPD (Ridwan et al., 2008). Dibandingkan dengan petani di Kabupaten Kambas, Kalimantan Barat, penggunaan perangkap kuning untuk pengendalian hama sangat terkenal di kalangan para petani jeruk di Kabupaten Karo. Menurut para petani di Kambas, penerapan perangkap kuning susah diterapkan di lahan jeruk mereka karena kurangnya pengetahuan dan keterampilan dalam aplikasi teknologi perangkap kuning dan juga karena bahan untuk membuat perangkap sulit diperoleh di lokasi setempat (Ridwan et al., 2008). Di lokasi penelitian, petani melakukan pembiaran tanman liar atau gulma tumbuh disekitar pohon jeruk siam karena dapat mengurangi serangan hama

Serangan CVPD atau citrus greening atau huanglongbin dapat menurunkan produktivitas jeruk siam di Kabupaten Karo. Penyakit ini disebabkan oleh Liberobacter asiaticum. Bakteri ini hidup dalam floem tanaman jeruk dan menimbulkan gejala khas (Wijaya et al., 2017). Tanaman jeruk siam dapat terserang CVPD dari bibit yang sudah terinfeksi CVPD atau melalui penular (vektor) dari kutu loncat Diaphorina citri. Pengendalian telur D. Citri dapat menggunakan insektisida berbahan endosulfan $0.05 \%$ pada awal pertunasan. Selain dengan insektisida, kutu loncat jeruk dapat dikendalikan dengan menggunakan cendawan Beauveria bassina (Bals.) Vuill. Sebagai miko-insektisida (Permadi et al., 2017). Gejala yang muncul jika tanaman jeruk terserang CVPD adalah tulang daun berwarna hikau tua dan laminar daun berwarna lebih muda dan lama kelamaan akan menguning (Sitorus et al., 2016).

\section{KESIMPULAN}

Para petani responden menganggap bahwa pembibitan paling penting saat mengembangkan usaha tani jeruk siam. Jeruk Japansche citroen cocok digunakan sebagai batang bawah untuk mendapatkan bibit jeruk 
Endang Christine Purba \& Bambang S. Purwoko: Teknik Pembibitan, Pemupukan, dan Pengendalian Hama Penyakit Tanaman Komoditi Jeruk Siam (Citrus Nobilis Var. Microcarpa) di Kecamatan Simpang Empat dan Kecamatan Payung, Kabupaten Karo, Sumatra Utara, Indonesia

siam yang bermutu terutama bebas penyakit.

Pembibitan dilakukan dengan menggunakan okulasi irisan.

Pemupukan dilakukan dengan menggunakan pupuk anorganik dan organik. Pupuk anorganik yang digunakan adalah urea, ZA, SP-36, dan ZK yang diterapkan sebanyak 3-4 bulan sekali. Petani juga menggunakan pupuk kandang sebagai pupuk organik setiap 10 bulan sekali.

Pengendalian hama penyakit tanaman jeruk siam dilakukan secara kimiawi dan mekanis. Pestisida disemprot sebanyak satu kali dalam 10 hari. Fungisida yang digunakan adalah bahan aktif difenokonazol yang memiliki konsentrasi $200 \mathrm{cc} / 100$ liter air untuk $1.000 \mathrm{~m}^{2}$. Sedangkan insektisida yang digunakan mengandung karbosulfan yang memiliki konsentrasi 200 cc/100 liter air untuk $1.000 \mathrm{~m}^{2}$. Perangkap kuning untuk pengendalian secara mekanis.

\section{UCAPAN TERIMAKASIH}

Penulis mengucapkan terimakasih kepada masyarakat di Kecamatan Payung dan Kecamatan Simpang Empat, Kabupaten Karo, Sumatra Utara yang sudah banyak membantu penulis selama penelitian. Penulis juga mengucapkan terimakasih kepada pemerintahan setempat baik di Kabupaten Karo, Kabanjahe, Sumatra Utara dan juga pemerintahan Kecamatan Simpang Empat dan Kecamatan Payung, Kabupaten Karo, Sumatra Utara.

\section{DAFTAR PUSTAKA}

Ashari H, Z Hanif, dan A Supriyanto. 2014. Kajian dampak iklim ekstrim curah hujan tinggi (La-Nina) pada jeruk siam (Citrus nobilis var. Microcarpa) di Kabupaten Banyuwangi, Jember dan Lumajang. Planta Tropika Journal of Agro Science, (2)1: 49-55

Balai Penelitian Tanaman Jeruk dan Buah Subtropika. 2014. Prospek berkebun jeruk JC (Japanche citroen). Online at

http://balitjestro.litbang.pertanian.go. id/prospek-berkebun-jeruk-jcjapanche-citroen/ [diunduh pada tanggal 31 Juli 2018].

Balai Penelitian Tanaman Jeruk dan Buah Subtropika. 2015. Pengelolaan terpadu kebun jeruk sehat. Online at http://balitjestro.litbang.pertanian.go. $\mathrm{id} /$ pengelolaan-terpadu-kebun-jeruk- sehat/ [diunduh pada tanggal 1 Agustus 2018].

Balai Penelitian Tanaman Jeruk dan Buah Subtropika. 2017. Membangun kebun jeruk. Online at http://balitjestro.litbang.pertanian.go. $\mathrm{id} /$ membangun-kebun-jeruk/ [diunduh pada tanggal 3 Agustus 2018].

Direktorat Jendral Hortikultura. 2015. Statistik produksi hortikultura tahun 2014. Kementrian Pertanian, Jakarta, Indonesia. 286 hal

Endarto O dan E Martini. 2016. Pedoman budi daya jeruk sehat. Bogor, Indonesia: World Agroforestry Center (ICRAF) Southeast Asia Regional program. 99 hal

Pemerintah Daerah Kabupaten Karo. 2017. Gambaran umum Kabupaten Karo. Online at 
http://www.karokab.go.id/id/profil/g ambaran-umum [diunduh pada tanggal 31 Juli 2018].

Permadi M A, R Anwar, dan T Santoso. 2017. Pemanfaatan cendawan Beauveria bassina (Bals.) Vuill. Sebagai miko-insektisida terhadap kutu loncat jeruk Diaphorina citri Kuw. (Hemiptera: Liviidae). Jurnal Biologi Lingkungan, Industri, Kesehatan, 4(1): 82-89.

Rambe SSM dan L Ivanti. 2013. Pengaruh pemupukan dan pemangkasan terhadap kualitas buah jeruk Gerga Lebong. Online at http://bengkulu.litbang.pertanian.go.i d/ ind/images/dokumen/2014/prosiding 13/bddy-pertanian/jeruk.pdf [diunduh pada tanggal 10 Agustus 2018].

Ridwan HK, A Ruswandi, Winarno, A Muharam, dan Hardiyanto. 2008. Sifat inovasi dan aplikasi teknologi pengelolaan terpadu kebun jeruk sehat dalam pengembangan agrin=bisnis jeruk di Kabupaten Sambas, Kalimantan Barat. Jurnal Hortikultura, 18(4): 477-490.

Sariningtias NW, R Poerwanto, dan E Gunawan. 2014. Penggunaan Benzil Amino Purin (BAP) pada okulasi jeruk keprok (Citrus reticulata). J. Hort. Indonesia, 5(3): 158-167.
Sitorus OF, IN Wijaya, dan NM Puspawati. 2011. Deteksi keberadaan penyebab penyakit Citrus Vein Phloem Degenartion (CVPD) pada tanaman jeruk dengan gejala menyeluruh menggunakan teknik Polymerase Chain Reaction (PCR). E-Journal Agroekoteknologi Tropika, 5(4): 354-362.

Sutopo S. 2009. Rekomendasi pemupukan untuk tanaman jeruk. Online at http://balitjestro.litbang.pertanian.go. id/rekomendasi-pemupukan-untuktanaman-jeruk/ [diunduh pada tanggal 15 Desember 2018].

Sutopo S. 2014. Dua belas macam unsur esensial yang dibutuhkan oleh tanaman jeruk. Online at http://balitjestro.litbang.pertanian.go. id/12-macam-unsur-esensial-yangdibutuhkan-oleh-tanaman-jeruk/ [diunduh pada tanggal 7 Agustus 2018].

Sutopo S. 2014. Panduan budidaya tanaman jeruk. Online at http://balitjestro.litbang.pertanian.go. $\mathrm{id} /$ panduan-budidaya-tanaman-jeruk/ [diunduh pada tanggal 7 Agustus 2018].

Wijaya IN, W Adiartayasa, IGP Wirawan, M Sritamin, M Puspawati, dan IM Sudarma. 2017. Hama dan penyakit pada tanaman jeruk serta pengendaliannya. Buletin Udayana Mengabdi, 16(1): 51-57. 